\title{
Tariff Impact on Industrialization in Tanzania: Evidence from Edible Oil Sub-Sector
}

\author{
Charles Peter Mgeni ${ }^{1,2} *$ \\ ${ }^{1}$ Department of Agricultural Economics, Humboldt University of Berlin, \\ Rudower Chaussee 16, 10099 Berlin, Germany \\ ${ }^{2}$ Leibniz Centre for Agricultural Landscape Research (ZALF e. V), \\ Eberswalder Str. 84, 15374, Müncheberg, Germany \\ E-mail: charles.mgeni@zalf.de \\ Klaus Müller ${ }^{1,2}$ \\ ${ }^{1}$ Department of Agricultural Economics, Humboldt University of Berlin, \\ Rudower Chaussee 16, 10099 Berlin, Germany \\ ${ }^{2}$ Leibniz Centre for Agricultural Landscape Research (ZALF e. V), \\ Eberswalder Str. 84, 15374, Müncheberg, Germany \\ E-mail: kmueller@zalf.de \\ Stefan Sieber ${ }^{1,2}$ \\ ${ }^{1}$ Department of Agricultural Economics, Humboldt University of Berlin, \\ Rudower Chaussee 16, 10099 Berlin, Germany \\ ${ }^{2}$ Leibniz Centre for Agricultural Landscape Research (ZALF e. V), \\ Eberswalder Str. 84, 15374, Müncheberg, Germany \\ E-mail: stefan.sieber@zalf.de
}

The research is financed by the Federal Ministry of Food and Agriculture under the auspices of the Federal Office for Agriculture and Food, Germany

\section{Abstract}

Developing countries implement protectionist policies like imposing tariffs, with the aim of promoting domestic production. This study assesses the impact of the imposed tariffs on edible oil on Tanzania's economy using a recursive dynamic computable general equilibrium model (CGE). Findings from this study show that implementing the tariff intervention on the dibble oil sub-sector has two principle outcomes; first, it triggers domestic producers to supply more due to the rise in demand and prices for the commodities, thus increases domestic production to meet demand; second, it reduces imports, consequently, decreasing citizens' welfare by limiting the availability and access options from imported commodities. Protectionist policies, when solely used as a solution to increase domestic production in a sector that is inefficient in terms of productivity, creates a supply deficit in the market, thus reducing consumers' welfare. Therefore, to improve sustainability and increase industrial competitiveness, it is imperative to promote policies and interventions that target increasing productivity. Interventions, like the use of improved seed and other modern technologies, that reduce costs of production are critical as commodities will be sold at a slightly competitive premium or the same prices as imported commodities.

Keywords: Tariff; Industrialization; Edible oil; Recursive dynamic CGE; Tanzania

DOI: $10.7176 / \mathrm{JESD} / 10-10-02$

Publication date:May $31^{\text {st }} 2019$

\section{Introduction}

Tanzania has transformed from a low-growth to a high-growth economy. For instance, macroeconomic indicators, such as GDP, consistently shows robust economic growth rates exceeding 7\% (URT 2016; BoT 2018). However, the high economic growth rate per se does not translate or go hand-in-hand with income distribution among the citizens. It could be that the high economic growth rate is fuelled by a few sectors; in this case, the growth mostly manifests in the service and industry sectors (Mufuruki et al 2017; BoT, 2018). The average growth rate for the service and industry sectors between 2006 and 2015 was 8\%, while the agriculture sector stagnated around 4\% per annum, marginally exceeding Tanzania's annual population growth rate of 3\% over the same period (URT 2016). Consequently, as noted by Jerven (2010) and Jerven and Duncan (2012), indicators of economic growth based on a macroeconomic indicator, such as GDP, cannot be used to make claims about economic development without considering the full picture upon which it is constructed.

Furthermore, economic development history shows that developed countries became advanced through the development of the agriculture sector, achieving substantial productivity growth by targeting food self-sufficiency and raw materials for growing industries (Bezemer and Headey 2008; Bresnahan et al. 2016; Clapp 2017). Agricultural-led development pathways with government support programs are not just deemed essential for 
achieving rapid economy-wide growth, but also poverty reduction in rural areas of developing countries. In addition, increasing agricultural productivity is a vital driver underlying industrialization, particularly in terms of raw material supply for agro-industries as well as food for the industrial workforce, growing population, and exports of the surplus (Flentø and Ponte 2017; Lectard and Rougier 2018).

In lieu of the above, trade and development theorists have differing views on which pathway to take: either adopting a free trade strategy that is assumed to impact the outflow and inflow of commodities in the country, thus accelerating raw materials production and industrialisation, or adopting a protectionist policy that seeks to stimulate domestic production of various commodities that will subsequently facilitate industrialization. Tanzania, like many other developing countries, has a strong agricultural base and is on the verge of choosing which trade strategies that will enable it to achieve high economic growth and develop its industrial potential. However, Tanzania's agriculture sector is extremely diverse, with crop production accounting for 55\% of agricultural GDP, livestock accounting for 30\%, and natural resources accounting for 15\% (URT 2016). The primary traditional cash and export crops are sugar, coffee, cotton, tobacco, tea, and cashew nuts, while the most prevalent staple crops include maize, cassava, rice, sorghum, and millet. Moreover, emerging non-traditional cash crops, such as edible oil crops, are playing an increasingly larger role.

Edible oil crops, like sunflower and groundnuts, are now major cash crops in semi-arid and arid regions of Tanzania (BoT 2018). These crops, especially sunflower, are grown in most parts of the country, with sunflower being drought resistant, less susceptible to diseases, and cheaper to cultivate than other oilseeds crops (URT 2016). Moreover, demand for sunflower oil and its by-products, such as seed cake, is increasing (TEOSA 2012); consequently, improving the sub-sector could significantly increase its contribution to economic growth and poverty reduction in the country (TEOSA 2012; Ugulumu and Inanga 2013; URT 2015). In addition, domestic edible oil production provides only 40 percent of local demand, with the remainder imported (Balchin et al. 2018; Mgeni et al. 2018; Ulugumu an Inanga 2013). Edible oil importation increased from 0.3 million tonnes in 2012 to 0.5 million tonnes in 2015, resulting in massive foreign currency outflows of US\$ 83.2 million annually (BoT 2018). The government of Tanzania is eager to reduce the country's dependence on imported edible oil by boosting domestic production and processing capacity, thus ensuring that more oil seeds and downstream edible oil products are produced locally (Balchin, et al. 2018). To do so, it is necessary to identify appropriate interventions that facilitate inclusive economic growth and income distribution throughout the sector and Tanzania as a whole. Therefore, the government opted to implement a protectionist policy for the edible oil sector by gradually imposing tariffs, starting at $10 \%$ in $2016 / 17$, rising to $25 \%$ for $2017 / 18$, and reaching $35 \%$ for $2018 / 19$, on both crude and refined edible oil with the aim of promoting domestic production. It is expected that the intervention will create more employment, not only in the edible oil sub-sector but also in other sectors in the economy. However, there is no empirical evidence concerning the extent to which, and pathways through which, the opted policy intervention will help promote job creation, increase domestic edible oil production, and accelerate industrialization, thus reducing poverty in the rural areas. Moreover, whatever evidence that may exist does not emanate from the use of economic multipliers analysis models, where the consequences of stimulating one sector of the economy and its spill over into other sectors are evaluated.

Few studies evaluate the impacts of tariffs on the edible oil sub-sector. For instance, a study by Mgeni et al. (2018) assesses the effects of an imposed 10\% tariff on the comparative advantage of domestically produced edible oil versus imported palm oil using a policy analysis matrix (PAM), finding that high costs for domestic edible oil producers renders their products uncompetitive against imported edible oils. A study by Balchin, et al. (2018) on tariff setting for the development of the sunflower sub-sector in Tanzania, uses a mixed method of literature review, survey, and stakeholder consultation. In this study, the emphasis is on the impact of the tariff on demand and supply dynamics. Findings highlight the effect of the tariff on the promotion of domestic production but do not show its linkage to economic growth and industrialization. Moreover, the authors are not aware of any other studies analyzing the economy-wide effects of an imposed tariff on the edible oil sector within a multi-sectoral national model and comparing its results to other sectors.

This paper bridges this research gap by applying a recursive dynamic computable general equilibrium model (CGE) at the national level, disaggregating the edible oil sub-sector from the agricultural sector and other sectors, and evaluating its multiplier effects on the Tanzanian economy. This study assesses the impact of the imposed tariffs on edible oil in Tanzania over five years at different tariff rates. We hypothesize that imposing the tariff could improve domestic production and contribute to industrialization. The research question is, does the imposed tariffs promote the edible oil value chain and substantially increase the sector's contribution to economic growth and industrialization? Hence, we answer this question by analyzing the effects of changes in macroeconomic specific indicators on the edible oils sub-sector in comparison to other sectors and the impact of gradually decreasing, to complete elimination of, the tariff over five years.

This study continues with a literature review on the edible oil sub-sector and industrialization paths in Tanzania (section 2), then the methodological framework for analyzing the effect of the imposed tariff using CGE is provided (section 3). Macroeconomic indicators like employment, commodity consumption, imported 
commodities prices changes, investment, and GDP are explained in the results (section 4), and, finally, we conclude by highlighting the implications of the findings from this study (section 5).

\section{Theoretical and empirical literature of Tanzanian industrialization and agriculture 2.1 Industrialization path in Tanzania since independence}

Like other developing countries in African and beyond, the Tanzanian industrialization process has evolved through various pathways since independence in 1961. Up to the mid-1960s, it embraced private sector driven industrial development, which was backed by the 1961-4 three-year and the 1964-9 five-year plans. These plans mainly promoted basic consumer goods processing industries (Szirmai and Lappene 2001; CTI 2000; Le Goff and Singh 2014; Mkubwa 2014). During the 1964-9 period, the Tanzanian government actively promoted the Import Substitution Industrialization (ISI) strategy. However, Msami and Wangwe (2015) point out the failure of these plans to advocate local ownership of the means of production and product mix, which subsequently hindered diversification and slowed down the broadening of the domestic industrial base.

Thereafter, from 1967 through the mid-1980s, the state abandoned private sector-led industrialization in favor of state-driven industrial development. The state-driven strategy was spearheaded by the Arusha declaration that, among its main manifestations, introduced state-led expansion and establishment of manufacturing industries (Msami and Wangwe 2016, Mufuruki et al. 2017). It was expected that the development and establishment of publicly owned enterprises would simultaneously expand the private sector. On the contrary, this led to a decline of the private sector and an increase in the number of publicly owned establishments that did not achieve the intended objectives, with many industries collapsing as a result of poor management and a lack of sense of ownership (Mwang'onda et al. 2018).

Subsequently, after 1986, the Tanzanian government reverted to private sector driven industrialization with the establishment of various programs, like the Economic Recovery Programme (ERP) of 1986-9, the Economic and Social Action Programme of 1989-92, the Sustainable Industrial Development Programme of 1996-2020, and the Integrated Industrial Development of 2011. All these programs advocated liberalization and privatization to facilitate industrialization (for more details see Szirmai and Lappene 2001; Msami and Wange 2016; Mufuruki et al. 2017).

The government launched a National Five-Year Development plan, 2016-2021, that aims to fill the gaps where previous targets were not achieved during the implementation of preceded plans (Mufuruki et al. 2017). To make the plan work, the government developed an industrial policy that underpins the details of what should be done to realize industrialization in Tanzania. The best option, as highlighted by UNIDO, (2012), Mwang'onda et al. (2018), and Cicowiez et al. (2016), is to focus on those sectors where the country has a comparative advantage. In particular, the chosen sectors should have a variety of job opportunities that cut across the Tanzanian labor endowment. This contrasts with the prior capital-intensive industries focus that failed to bring jobs to the Tanzanian labor force, as argued by De Ferranti et al. (2002), Morris and Fessehaie (2014) and Wangwe et al. (2014). Accordingly, one action undertook by the government is to nurture domestic labor-intensive sectors and industries that are geared toward the production of goods and services that are in high demand domestically. Therefore, one sector given priority is the agricultural sector, underscoring the fact that, for a country like Tanzania, a prerequisite to industrialization is a rise in agricultural productivity and supply. As such, stagnant growth in the agricultural sector, which results in an insufficient supply of raw materials, hinders the expansion of food processing and manufacturing industries (Cramer 1999; Diao et al. 2012). Therefore, the Tanzanian government considers agriculture as a driver of growth, industrialization, social development, and economic development that hinges on its strong agricultural base, which employs about $68 \%$ of its population, especially in rural areas.

\subsection{Tanzania agriculture contribution to industrialization}

The Tanzanian government sees industrialization as key for the country to become a middle income and semiindustrialized economy by 2025. Tanzania's industrial sector is mainly comprised of manufacturing (53\%), processing (43\%), and assembling industries (4\%) (Msami and Wangwe 2016; Mufuruki et al. 2017; Mwang'onda 2018). Additionally, food processing makes up about $24 \%$ of the manufacturing sector, followed by textiles and clothing 10\%, and chemicals $8.5 \%$ (Mwang'onda et al. 2018). This implies Tanzania's industrial sector is centered on agricultural food processing. Therefore, developing the agriculture sector is considered to be a precursor to industrialization (Chongela 2015). However, Tanzania's agricultural potential is not fully exploited: out of the 44 million hectares of arable land, only $24 \%$ is cultivated; out of the 50 million hectares suitable for livestock, only 26 million are used (URT 2018). Thus, the government is promoting the development of appropriate and effective policies that will facilitate a transformation of agriculture that will lead to its expansion and increased productivity (Mkubwa 2014; Mufuruki et al. 2018). Another compelling reason to promote it is that, despite providing about $68 \%$ of the Tanzanian population employment, especially in rural areas (Chisoro-Dude et al. 2018; URT, 2018), its contribution to GDP is only $10 \%$, which is very low compared to other sectors (BoT 2018). Therefore, promoting the sector should lead to increased job creation, poverty alleviation, and economic growth. In addition, 
the sector is expected to supply raw materials to the industrial sector, supply food to the industrial labor force, and create a market for the manufactured commodities. Consequently, in 2015/16, the government launched the tenyear Agricultural Sector Development Programme II (ASDP II), an instrument designed to achieve the 2025 Tanzania Development Vision (TDV) and its goal to develop the agriculture sector such that it increases its contribution to GDP (URT, 2016). Identified as the most likely sub-sector to yield investable opportunities, especially for domestic producers and processors, the edible oils sub-sector is among the priority commodities selected for promotion within the ASDP II framework (BoT 2018).

\subsubsection{The contribution of the edible oil sub-sector to industrialization}

In Tanzania, like most Sub-Saharan countries, edible oil crops are among the most vibrant farming activities. There has been an expansion in the production of crops with high protein contents, such as soybean, groundnuts, rapeseed, palm oil, and sunflower seeds; all of which are used for direct consumption (TEOSA 2012). Currently, the annual edible oil demand in Tanzania is around 400,000 tons, an amount that is increasing at approximately the same rate as its population, 3\% annually (Kombe et al. 2017; Balchin et al. 2018; URT 2018). Moreover, data indicate that Tanzania's domestic production of both factory and small-scale extracted edible oils supplies about $40 \%$ of the national demand, with the rest imported (URT 2018; Mgeni 2018; Balchin et al. 2018). Consequently, edible oil importation results in massive foreign currency outflows annually (Kombe et al. 2017; BoT 2018), even though Tanzania's large arable land base confers a competitive advantage in producing edible oil domestically. Hence, the government is making a concerted effort to support the edible oils sub-sector by, among other actions, gradually raising tariff rates for edible oils from $10 \%$ in $2015 / 16$ to $35 \%$ in $2018 / 19$. It is expected that, as a protectionist strategy, it will protect domestic producers and increase domestic production of edible oils to the point where domestic demand is met and the surplus is exported.

\section{Methodology \\ 3.1 Data}

Tanzania's Social Accounting Matrix (SAM) data used for the recursive dynamic edible oil tariff simulation model, abbreviated as PEP-EDTASIM, are from the Nexus project led by the International Food Policy Research Institute (IFPRI 2017). The original 2015 SAM is disaggregated into sixty-eight sectors and seventy commodities; however, for the PEP-EDTASIM we aggregate into eight sectors and commodities (agriculture, edible oil, food and beverage, agro-processing, mining and gas, industries, administration, and service). Furthermore, we broadly categorize the factors into labor, capital, and land, from which the labor is further disaggregated into rural unskilled, rural skilled, urban unskilled, and urban skilled, while the capital is disaggregated into agriculture (crops and livestock) and other industries. In addition, we consider an open economy where four agents are actively involved: the government, firms, households, and the rest of the world. To see how the tariff impacts different groups of citizens, we further disaggregate the household agent into rural farming, rural non-farming, and urban households. Apart from the SAM data, the PEP-EDTASIM requires exogenous data, including income, trade and substitution elasticities, and the population growth rate for calibration so that it reproduces and mimics the base year data in the economy before running the simulation. There are various ways of obtaining these elasticities, either estimations from country household survey and trade data or borrowing from previous studies. Here we use elasticities from Laborde and Traore (2017) and the population growth rate from the United Republic of Tanzania (2018) population prediction reports.

\subsection{Model description}

The PET-EDTASIM model framework used for this study is a recursive dynamic computable general equilibrium model developed by Decaluwe et al. (2013). The model does not take into consideration intertemporal optimization in the way that intertemporal dynamic models do (Féménia and Gohin 2011; Pratt et al. 2013; Taylor 2016; Van Ha and Kompas 2016; Minor et al. 2017; Raihan et al. 2017). Therefore, dynamism is handled in two ways in PEP-EDTASIM; first, each period is considered as static equilibrium, with starting variables inherited from the previous period and, second, there is an accumulation of capital over time that is assumed to accelerate economic growth. Moreover, the model considers population growth over time, assuming a population index that is growing each period depending on the country growth rate; for this case, we use a constant growth rate of $3 \%$ as predicted by the United Republic of Tanzania (URT 2018). We use the population index for updating values, constants, and parameters that are expected to grow at the same rate. A constant growth rate causes the model to simulate a balanced growth path where all quantities grow at a constant rate, thus maintaining relative prices. Moreover, balanced growth is also used as a test for model consistency and as a base scenario. As mentioned in the SAM description, the PEP-EDTASIM considers eight activities and commodities. It is expected that the government's policy intervention will impact these sectors, subsequently manifested by the agents (government, households, firms, and the rest of the world) in the economy. The impact is considered in terms of production, consumption, income, employment (labor demand), capital accumulation, and price changes over time.

Therefore, we assume that individual firms during the commodities production process act in a competitive 
manner, aiming to maximize profits subject to its production technology at given prices. These firms at the top combine value-added intermediate inputs at a fixed share using a Leontief production function. Firms at the second level combine composite capital and labor using the constant elasticities of substitution (CES) specification to obtain the value-added. Therefore, whether firms aim at maximizing profit or minimizing costs, they will continue to employ labor and capital to the extent that the value of the marginal product of labor and capital equal the wage rate and rental rent, respectively. Therefore, a firm's income comprises of the share from the capital income and of transfers received from other agents. Consequently, the demand for labor and capital by firms creates income for households with a fixed share of earnings. Other sources of household income are from transfer payments from the government and other agents, which is also assumed to grow over time. After taxes and transfers to other agents, the total income received by households is dedicated to consumption and savings. The savings are assumed to follow a linear function of disposable income and grow over time rather than a fixed proportion of income following the argumentation by Decaluwe et al. (2013). The tariff imposed by the government on the edible oil sector is expected to have twin effects: on the one hand, it is expected to encourage domestic production by protecting domestic producers, while, on the other hand, it should increase government revenues. Government revenues come from households, taxes on business income, transfers from agents, products, productions, and import duties. In our model, we gradually decrease the imposed tariffs from $45 \%$ to $0 \%$ in the fifth year and assume annual population growth of $3 \%$. Consequently, we observe the predicted outcome from the model on the hypothesized indicators that may lead to improvement of citizens' welfare and an increase in capital formation, which, in turn, is used for investments that fuels economic growth. Moreover, the import tariff intervention is taken as an inward-oriented strategy that promotes industrialization through import substitution. This is assumed to influence capital, technology, and product inflow from outside the country, which is observed through the rest of the world imports and export payments, as well as changes of expenditure to the domestic economy over the given period. In addition, we adopt macroeconomic closure rules where the exchange rate is a numeraire, while government expenditure, saving- investment balances, and public sector investment are fixed for each of the simulation scenario periods. Capital stock resulting from capital accumulation is considered exogenous for each period. We also conduct a homogeneity test alongside our PEP-EDTASIM model, where we change the nominal variables and prices that are constant in the closure, and since relative prices are only considered in CGE models, a change of the numeraire does not affect the volume variable level instead it changes values in the same proportion as the numeraire. Finally, detailed documentation and derivation of equations for all the blocks are in Decaluwe et al. (2013).

\subsection{Scenario description}

In economic development literature, and as noted by Fosu (2011), economic development in Sub-Saharan African countries requires economic growth. With economic growth, the state can generate more output and income, thus enabling a sustainable reduction in poverty, unemployment, and other societal problems (Chen and Ravallion 2013; Hübler and Pothen 2017; Pothen and Welsch 2018). This raises the question: what strategies help countries achieve economic growth? One option is to adopt industrialization, which advocates claim will achieve rapid economic growth. However, achieving industrialization brings two polarizing arguments: either a country follows the free trade strategy, with the free inflow and outflow of factors, technologies, and commodities, or the country imposes some restrictions on free flows (Yu et al. 2011; Mitra and Shin 2012; Thomas, et al. 2013; Koopman, et al. 2014; Kosack and Tobin 2015; Bouet et al. 2017; Porteous 2017; Aragie, et al. 2018).

The Tanzania government chose a restriction strategy on imported edible oil, gradually raising the ad valorem tax from $10 \%$ in $2016 / 17$ to $35 \%$ in the $2018 / 19$. Therefore, the PEP-EDTASIM is calibrated at the base year to mimic the economic structure of Tanzania's 2015 SAM and run for five years to create a baseline balanced growth path. Thereafter, counterfactual simulations are run by introducing changes to the variables of the policy in question. In this case, we impose tariff changes in the model by gradually decreasing tariff rates from $45 \%$ to complete tariff removal $(0 \%)$, which, for the convenience of presentation, are denoted as $\mathrm{T}_{1}, \mathrm{~T}_{2}, \mathrm{~T}_{3}, \mathrm{~T}_{4}$, and $\mathrm{T}_{5}$ representing tariff rates of $45 \%, 35 \%, 25 \%, 15 \%$, and $0 \%$, respectively. However, with respect to the tariff rates, we start with a slightly higher threshold tariff rate of $45 \%$ than the actual implemented $35 \%$ for the $2018 / 19$ so that we can capture the impact if tariff rates continue to rise. Hence, percentage changes in the macroeconomic variables hypothesized for this study are compared to the base period for each counterfactual simulation that is predicted by the model.

\subsection{Results and Discussion}

\subsection{Tanzania Macroeconomics indicators 2015}

Macro-economic indicators in Tanzania's aggregate national accounting indicates that private consumption makes up a majority share of the GDP, about 59\%, followed by fixed investment making up about $38 \%$. Empirical findings from Tvaronvicius (2008), relating economic growth to capital formation, suggest that fixed investment significantly influence economic growth. However, it is important to note that the influence of fixed investments 
on economic growth will depend on which the sector the investment is taking place and its distributional impact across the whole population. In Tanzania, as noted earlier, a large part of the community is involved in the agricultural sector, which has a low growth rate. Thus, increasing investment in this sector will impact a large part of the population. Moreover, results indicate that government consumption is about $16 \%$, while the net indirect tax is approximately $9.5 \%$. The factor cost takes a share of roughly $90.5 \%$, this implies the net income from the sales of commodities is quite small. Furthermore, findings indicate that Tanzania is a net importer with a composite commodity absorption of about $105 \%$ of GDP, while exports make up about $23 \%$ and imports about $28 \%$. Stock change shows a discrepancy of about $8 \%$ (Table 1 ).

Table 1. Aggregate national accounting summary base year 2015

\begin{tabular}{lcr}
\hline Macroeconomic Indicator & Value (TZ '000 billion) & Percentage-GDP \\
\hline Absorption & 69.33 & 105.06 \\
Private consumption & 38.98 & 59.07 \\
Fixed investment & 24.89 & 37.71 \\
Stock change & -5.21 & -7.89 \\
Government Consumption & 10.67 & 16.17 \\
Exports & 15.09 & 22.87 \\
Imports & -18.43 & -27.93 \\
GDP Market Price & 65.99 & 100 \\
Net indirect tax & 6.29 & 9.53 \\
GDP at factor cost & 59.70 & 90.47 \\
\hline
\end{tabular}

\subsection{Simulation Scenario outcomes}

\subsubsection{The effects of the tariff increase on import commodities}

Results from this study indicate that at high tariff rates, imports of edible oil fall tremendously, while, for the other sectors, the imported amounts increase slightly. This means that imposing high tariffs on the edible oil sub-sector has a direct effect on the sub-sector, causing traders to switch to importing commodities that have lower tariffs than those for edible oils (Table 2). Although the demand for commodities is a function of income and price elasticities, tariffs add costs to imported commodities; consequently, causing a price increase in the domestic market. On the one hand, this is the desired outcome for domestic edible oil producers, as it creates a deficit of the commodity in the market, ultimately raising the price for domestically produced edible oil. Moreover, as demand for edible oil increases in the domestic market, domestic producers are motivated to produce more to meet the growing demand. On the other hand, as noted by Mgeni, et al. (2018) and Balchin, et al. (2018), as demand for edible oils rises, but the speed of adjustment for domestic producers is low, a supply deficit is created, adversely affecting consumers. Therefore, the intervention has two consequences: on the one hand, it incentivizes domestic producers to supply more, due to the rise in demand for the commodity. Similar findings are noted by Page (2012) and Moris et al. (2012) that, increasing domestic products production could meet the material demanded by the agro-processing and other extractive industries, such as mining. On the other hand, from the perspective of international trade, such intervention erodes citizen welfare by limiting access to varieties of commodities that could make them better off in terms of price, quality, and quantity. However, the increase in domestic output enables the commodity processing industries in question to achieve economies of scale in terms of quality, varieties, and quantities, thus filling the welfare losses triggered by the importation barrier strategy. Similarly, Mwakwiramiti (2011) and Adewale (2017) argue that imposing tariffs as an import substitution industrialization (ISI) policy stimulated industrialization in the BRICS countries. Furthermore, the imposition of tariffs can be used as a short run measure, allowing domestic industries to grow and achieve the desired level of industrialization; subsequently, in the long run, trade liberalization can come into play. Thus, promoting domestic commodities that support the expansion of agro-processing may be considered as an appropriate path toward industrialization for countries with a strong agricultural base like Tanzania.

Table 2 . The effect of the tariff increase on quantity of imported products ( $\%$ change from BAU)

\begin{tabular}{lrrrrr}
\hline \multirow{2}{*}{ Commodity } & \multicolumn{5}{c}{ Tariff rate } \\
\cline { 2 - 6 } & $\mathrm{T}_{1}$ & $\mathrm{~T}_{2}$ & $\mathrm{~T}_{3}$ & $\mathrm{~T}_{4}$ & $\mathrm{~T}_{5}$ \\
\hline Agricultural & 0.04 & 0.03 & 0.02 & 0.01 & -0.01 \\
Edible Oils & -50.55 & -43.29 & -34.26 & -22.84 & 0.90 \\
Food \& Beverage & 0.04 & 0.03 & 0.02 & 0.02 & \\
Agro-processing & 0.06 & 0.06 & 0.04 & 0.03 & \\
Mining \& Gas & 0.02 & 0.02 & 0.02 & 0.01 & 0.01 \\
Industrial & 0.06 & 0.05 & 0.04 & 0.03 & \\
Administration & 0.01 & 0.01 & 0.01 & 0.01 & \\
Service & 0.03 & 0.02 & 0.02 & 0.02 &
\end{tabular}

Note: BAU:-Business as usual 


\subsubsection{The effects of the tariff increase on export commodities}

Results from the model predict a decrease in the export of commodities to all. However, at a lower tariff $\left(\mathrm{T}_{4}\right)$ and complete removal of tariff $\left(\mathrm{T}_{5}\right)$, exports start to increase for the agriculture, industries, and edible oil sectors. A noticeable increase is predicted for edible oils; this implies that the edible oil sector depends heavily on the importation of crude, semi-refined, and refined oils. In particular, the crude and semi-refined edible oils are reprocessed and exported to neighboring countries like the Democratic Republic of Congo (DRC), Rwanda, and Kenya; as also reported by Balchin et al. (2018). Therefore, as international trade theory suggests, the imposition of high tariff rates could lead to an export contraction in some sectors, which subsequently can slow down industrialization if the output growth in the protected sectors does not match with commodities demanded by the growing industries. This is consistent with the findings of Chang (2012), Mkubwa (2014), Msami and Wangwe (2016), Mufuruki et al. (2017), and Mwang'onda (2018), which argue that whenever an import tariff is imposed to protect domestic industries, a subsequent decrease in exports is expected in the short run due to imbalances in domestic supply and demand. Therefore, the domestic production expansion adjustments in the protected sectors should be geared toward fulfilling domestic demand, with a reduced focus on export markets. Samouel et al. (2016) also note that, in the long run, when desired domestic commodities' outputs are achieved, an increase in imports and exports is required to further increase capital and technology inflow and outflow to partner countries, which may increase industrialization and welfare (Table 3 ).

Table 3 . The effects of the tariff increase on export commodity ( $\%$ change from BAU)

\begin{tabular}{|c|c|c|c|c|c|}
\hline \multirow{2}{*}{ Commodity } & \multicolumn{5}{|c|}{ Tariff rates } \\
\hline & $\mathrm{T}_{1}$ & $\mathrm{~T}_{2}$ & $\mathrm{~T}_{3}$ & $\mathrm{~T}_{4}$ & $\mathrm{~T}_{5}$ \\
\hline Agriculture & -0.03 & -0.03 & -0.02 & -0.01 & 0.01 \\
\hline Edible Oils & -0.29 & -0.16 & -0.05 & 0.04 & 0.15 \\
\hline Food \& Beverage & -0.02 & -0.02 & -0.02 & -0.01 & \\
\hline Agro-processing & -0.07 & -0.07 & -0.05 & -0.03 & \\
\hline Mining \&Gas & -0.01 & -0.01 & -0.01 & -0.01 & \\
\hline Industries & -0.03 & -0.02 & -0.02 & -0.01 & 0.01 \\
\hline Administration & -0.02 & -0.02 & -0.01 & -0.01 & \\
\hline Service & -0.02 & -0.02 & -0.01 & -0.01 & \\
\hline
\end{tabular}

4.2.3 The effect of the tariff increase on demand for the locally produced commodities

Results from this study, as shown in Table 4, indicate that, with an increase in tariffs for edible oils, the demand for domestically produced edible oil increases at higher tariff rates and gradually decreases as the tariff rates decrease. The impact of the imposed tariffs on demand for locally produced goods depends, first, on how large is the price change for the supplied commodity; if the price change is significant, then commodity demand will fall. Second is the elasticity of demand of that commodity: how sensitive are consumers to price changes; for instance, food commodities are inelastic, therefore, a smaller impact is expected for food commodities. Similar findings are reported in studies conducted in Botswana by Mbayi $(2011,2013)$ regarding beneficiation policies adopted to protect domestic producers. These studies find an increase in demand for the locally produced commodities, which resulted in an acceleration and deepening in the development of local value chains. Additionally, a decreasing trend in the demand for other domestically produced commodities is observed for the agro-processed and other agricultural commodities; a situation aggravated by increases in the prices of the intermediate goods and valueadded, thus rendering higher prices for the final consumer products. Further, no change in demand for the industrial commodities is predicted at higher tariff rates; except if the tariff is eliminated, then the demand for industrial commodities increases. This implies the removal of tariffs reduces the cost of production, thus reducing prices for the final industrial produced goods.

Table 4. Domestic demand for the commodity produced locally ( $\%$ change from BAU)

\begin{tabular}{|c|c|c|c|c|c|}
\hline \multirow{2}{*}{ Commodity } & \multicolumn{5}{|c|}{ Tariff rate } \\
\hline & $\mathrm{T}_{1}$ & $\mathrm{~T}_{2}$ & $\mathrm{~T}_{3}$ & $\mathrm{~T}_{4}$ & $\mathrm{~T}_{5}$ \\
\hline Agricultural & -0.01 & -0.01 & -0.01 & & \\
\hline Edible Oils & 0.46 & 0.40 & 0.32 & 0.22 & 0.01 \\
\hline Agro-processing & -0.03 & -0.03 & -0.02 & -0.01 & \\
\hline Industrial & & & & & 0.01 \\
\hline Administration & -0.01 & -0.01 & -0.01 & -0.01 & \\
\hline
\end{tabular}

\subsubsection{The effects of the tariff increase on sectoral commodity supply to the domestic market}

Results of the model, shown in Table 5, predict an increase in the supply of commodities to the domestic market from various sectors. For instance, the supply of agricultural products from the agriculture sector to agroprocessing increases as tariff rates rise, while the supply of the agro-processing industry to agriculture decreases. The model also predicts growth in the supply of edible oils to the domestic market. This shows that the tariff intervention has a dichotomous effect on the supply of commodities to the domestic market, as it can both encourage and discourage production. Moreover, results indicate an increase of commodity supply from the 
industrial sector to the agro-processing, service, and food and beverage sectors. Similarly, Aragie et al. (2018), argue that policy geared toward restricting imports creates a commodity deficit in the domestic market, causing domestic producers or downstream industries to divert their supply to local markets, where the rise in prices means they can accrue high profits. Moreover, the model predicts a decrease in commodities supply from the industry sector to both agriculture and mining and gas, as well as from the food and beverage sector to industries and service. Moreover, a reduction in the amount of administrative expenditure is notable to the administration sector. This implies that the restriction causes a rise in prices for the intermediate inputs and raw materials required by the industrial sector, thus reducing the supply of commodities from the industrial sector to other sectors. Similar results are also reported by Laborde et al. (2013), who find that trade restrictions cause a decrease in intermediate inputs, especially for industries depending on imported intermediate inputs. Indeed, for Tanzania, in the short run, a reduction in the supply of raw material is expected, which is also consistent with what is noted by Mgeni et al. (2018), that there is a low speed of adjustment for domestic producers in Tanzania in responding to industrial demand for raw materials.

Table 5. Effects of the tariff increase on supply commodity to the domestic market (\% Change from BAU)

\begin{tabular}{llrrrrr}
\hline \multirow{2}{*}{ Sector } & \multicolumn{1}{c}{ Commodity } & \multicolumn{5}{c}{ Tariff rates } \\
\cline { 2 - 6 } Agriculture & Agricultural & $\mathrm{T}_{1}$ & $\mathrm{~T}_{2}$ & $\mathrm{~T}_{3}$ & $\mathrm{~T}_{4}$ & $\mathrm{~T}_{5}$ \\
& Agro-processed & -0.01 & -0.01 & -0.01 & & \\
& Industrial & -0.05 & 0.06 & 0.05 & 0.04 & 0.01 \\
Edible Oils & Edible Oils & 0.46 & -0.03 & -0.02 & & 0.01 \\
Food \& Beverages & Industrial & -0.02 & -0.02 & -0.02 & -0.01 & 0.01 \\
& Service & -0.02 & -0.01 & -0.01 & -0.01 & \\
Agro-processing & Agricultural & -0.09 & -0.11 & -0.09 & -0.06 & \\
& Agro-processed & -0.04 & -0.04 & -0.03 & -0.02 & \\
& Industrial & -0.11 & -0.12 & -0.10 & -0.06 & \\
Mining \& Gas & Service & -0.12 & -0.12 & -0.10 & -0.06 & 0.01 \\
Industries & Industrial & & -0.01 & -0.01 & -0.01 & -0.01 \\
& Agro-processed & 0.18 & 0.18 & 0.14 & 0.09 & \\
& Mining \& Gas & -0.01 & & 0.01 & 0.02 & 0.03 \\
& Industrial & 0.03 & 0.02 & 0.02 & 0.02 & \\
& Service & & 0.01 & 0.02 & 0.02 & 0.02 \\
Administration & Food \& Beverages & 0.03 & 0.03 & 0.02 & 0.01 & \\
\hline
\end{tabular}

\subsubsection{The effects of the tariff increase on different agents' income}

In this study, households are categorized into three groups: rural farming, rural non-framing, and urban households. Other agents are the government, business firms, and the rest of the world. Findings from the model predict an increase in income for all agents at the higher import tariff rates. Moreover, the model predicts greater income gains for rural farming households and the government. This indicates that high tariff rates on edible oils motivate farmers to produce more due to the increase in demand for domestically produced commodities that, in turn, increase household incomes. For the government, the collection of tax revenues increases with higher tariff rates, coupled with an increase in the production of domestically produced commodities. These results are consistent with those of Naranpanawa and Arora (2014) in their multiregional CGE model: their results indicate that protected agricultural-related industries contribute to the increasing income of rural farming populations in Indian states. Overall, results from the model suggest that higher tariffs result in increasing incomes for all economic agents and help to achieve the government's objective of reducing income inequalities across Tanzania's population. Similarly, Le Goff and Singh (2014) argue that promoting trade reforms that target sectors like agriculture, where developing countries have a comparative advantage, are critical for increasing the incomes and improving the livelihoods of rural farming households. In contrast, as tariff rates increase, there is a decrease in the quantity of imported edible oils, thus decreasing income inflow from the rest of the world. In this regard, it is important to note that welfare gains resulting from the increase in incomes for the other domestic economic agents and institutions are more than that from the rest of the world (Table 6). 
Table 6. The effects of the tariff increase on different agents' income ( $\%$ change from BAU)

\begin{tabular}{lrrrrr}
\hline \multirow{2}{*}{ Agent type } & \multicolumn{5}{c}{ Tariff rates } \\
\cline { 2 - 6 } & $\mathrm{T}_{1}$ & $\mathrm{~T}_{2}$ & $\mathrm{~T}_{3}$ & $\mathrm{~T}_{4}$ & $\mathrm{~T}_{5}$ \\
\hline Households & & & & & -0.01 \\
$\quad$ Rural farming & 0.05 & 0.04 & 0.03 & 0.01 & -0.01 \\
$\quad$ Rural non-farming & 0.03 & 0.02 & 0.02 & 0.01 & \\
$\quad$ Urban & 0.01 & 0.01 & 0.01 & 0.01 & \\
Government & 0.04 & 0.04 & 0.03 & 0.02 & \\
Firms & & 0.01 & 0.01 & 0.01 & \\
RoW & -0.01 & -0.01 & -0.01 & & \\
\hline
\end{tabular}

\section{Note: RoW: - Rest of the World}

\subsubsection{The effect of the tariff increase on different agents' savings}

Results in Table 7 show the model prediction, which indicates that, at higher tariff rates, savings increase for all household categories. Further, a larger increase in savings is observed for rural farming households than for rural non-farming or urban households. This implies that the higher tariff rates for edible oils motivate farmers to produce more, thus increasing their incomes and, ultimately, increasing their savings from the sale of agricultural commodities.

Moreover, for the case of rural non-farming households, higher tariff rates encourage the agricultural sector to produce more edible oil crops. This situation increases labor demand for the edible oil sector, which depends on non-farming households for a large share of its labor, thus increasing the income and savings for these employees. Similarly, at higher tariff rates, savings for the firms increase as a result of the increase in demand for the commodities that are sold at a higher price. Surprisingly, a decrease in savings is observed for the government as tariff rates increase, although one would expect an increase in revenue collections from the imported edible oils due to high tariff rates, the realized decrease in edible oils imports surpass the gains from the higher tariff rates, thus reducing governmental revenues.

Table 7 . The effect of the tariff increase on different agents' savings ( $\%$ change from BAU)

\begin{tabular}{lrrrrr}
\hline \multirow{2}{*}{ Agent type } & \multicolumn{5}{c}{ Tariff rates } \\
\cline { 2 - 6 } & $\mathrm{T}_{1}$ & $\mathrm{~T}_{2}$ & $\mathrm{~T}_{3}$ & $\mathrm{~T}_{4}$ & $\mathrm{~T}_{5}$ \\
\hline Household category & & & & & -0.01 \\
Rural farming & 0.05 & 0.04 & 0.03 & 0.01 & \\
Rural non-farming & 0.03 & 0.02 & 0.02 & 0.01 & 0.01 \\
Urban & 0.01 & 0.01 & 0.01 & -0.13 \\
Government & -0.23 & -0.21 & -0.18 & 0.01 \\
Business firms & & 0.01 & 0.01 & 0.01 \\
\hline
\end{tabular}

\subsubsection{The effect of the tariff increase on sectoral investment demand for capital and land}

Table 8 reports the predicted impact of the gradual reduction in tariff rates on sectoral demand for the factors of production, particularly capital and land. At high tariff rates, the model predicts an increase in demand for capital for the agriculture, edible oil, and industrial sectors. This implies that high tariff rates stimulate investments, especially in the edible oil sector, followed by the industry and agriculture sectors. Reasons for the increase in investment in the edible oil sector include the imposition of tariffs, which causes an increase in edible oil prices and demand that, in turn, motivates producers to invest in the sectors. Similarly, Mgeni, et al. (2018) and a report by URT (2018) note that promotion of the edible oil sector indirectly stimulates the production of other crops, as the mixed cropping system is commonly practiced by farmers. Moreover, capital demand for the industrial sector increases, presumably due to the increase in the production and supply of the agro-processing machinery and equipment needed for edible oil and other crops. In contrast, as tariff rates increase, a decrease in investment demand for capital is predicted for the agro-processing, service, and mining and gas sectors. Similarly, Balchin et al. (2018), Mgeni et al. (2018) and URT (2018) find that high tariffs reduce the amount of imported refined and crude edible oils, thus discouraging investment in the agro-processing sector. For land investment, an increase in demand is anticipated both for the agriculture and edible oils sectors. Similar reasoning as explained for the instance of investment demand for capital earlier hold for the land investment demand for these sectors. 
Table 8 . Investment demand on capital and land per sector ( $\%$ change from BAU)

\begin{tabular}{|c|c|c|c|c|c|c|}
\hline \multirow{2}{*}{\multicolumn{2}{|c|}{ Factor demand per sector }} & \multicolumn{5}{|c|}{ Tariff rates } \\
\hline & & $\mathrm{T}_{1}$ & $\mathrm{~T}_{2}$ & $\mathrm{~T}_{3}$ & $\mathrm{~T}_{4}$ & $\mathrm{~T}_{5}$ \\
\hline \multirow{7}{*}{ Capital } & Agriculture & 0.02 & 0.01 & & & \\
\hline & Edible Oils & 1.45 & 0.97 & 0.55 & 0.17 & -0.38 \\
\hline & Food \& Beverage & -0.01 & -0.01 & -0.01 & & 0.01 \\
\hline & Agro-processing & -0.30 & -0.13 & -0.03 & 0.05 & 0.12 \\
\hline & Mining \& Gas & -0.03 & -0.03 & -0.02 & -0.01 & 0.01 \\
\hline & Industries & 0.04 & 0.03 & 0.03 & 0.02 & \\
\hline & Service & -0.03 & -0.02 & -0.01 & & 0.02 \\
\hline \multirow[t]{2}{*}{ Land } & Agriculture & 0.02 & 0.01 & & & \\
\hline & Edible oil & 1.45 & 1.05 & 0.67 & 0.29 & -0.31 \\
\hline
\end{tabular}

4.2.8 The effect of the tariff increase on sectoral labor demand

Table 9 presents the impact of the gradual reduction in tariff rates on demand for labor. An increase in rural unskilled and urban unskilled labor demand is notable at higher tariff rates for the edible oil sector. This implies that higher tariff rates stimulate more production for the edible oil sector; therefore, the expansion of output creates more demand for labor. Similarly, an increase in demand for urban unskilled and skilled labor for the industry sector at higher tariff rates subsequently decreases as the tariff is wholly removed.

Moreover, an increase in urban unskilled and urban skilled labor demand at higher tariff rates is predicted for the food and beverage sector; however, it remains unchanged as tariff rates decrease from $\mathrm{T}_{3}(25 \%)$ to completed removal. This also could be an expansion of production for the edible oil sector. These results are consistent with those of Morris and Fessehaie (2014), who argue that developing countries' industrial policies at the initial stage of industrialization, should be formulated for unskilled labor-intensive sectors like agriculture. The authors further assert that, in the long run, unskilled labor needs to be facilitated in terms of knowledge and skills required by the developing industrial sectors. Similarly, Le Goff and Singh (2014) note improving income for the unskilled labor in the developing countries; effort should be to bridge the knowledge gap so that they move from the contracting to the expanding sectors.

In addition, Kosack and Tobin (2015) argue that trade liberalization causes the reallocation of economic activities that require the country to have skilled human capital capable of working for established economic activities. It is also interesting to note that, at higher tariff rates, labor demand across all labor categories decreases for the agro-processing sector. However, demand for rural unskilled, urban unskilled, and urban skilled labor increases as the tariff rates go from $\mathrm{T}_{4}(15 \%)$ to complete removal. This indicates that the raw material supply for the agro-processing sector heavily depends on the importation, such that, at higher tariff rates, there is a reduction in the supply of raw material, thus necessitating the sector to lay off workers. Generally, the model predicts a decrease in demand in the agriculture, mining, and gas, administration and service sectors for all categories of labor at higher tariffs rates. This results in demand for labor being shifted toward the stimulated edible oil sectors. Table 9. The effects of the tariff increase on sectoral demand for labor ( $\%$ change from BAU)

\begin{tabular}{|c|c|c|c|c|c|c|c|c|}
\hline \multirow[b]{2}{*}{ Labour Type } & \multicolumn{8}{|c|}{ Sectors } \\
\hline & Agriculture & Edible Oils & $\begin{array}{c}\text { Food } \\
\text { \&Beverage }\end{array}$ & Agro-processing & Mining \&Gas & Industries & Administration & Service \\
\hline \multicolumn{9}{|c|}{ Rural unskilled } \\
\hline $\mathrm{T}_{1}$ & -0.05 & 1.02 & -0.04 & -0.26 & -0.08 & -0.04 & -0.05 & -0.05 \\
\hline $\mathrm{T}_{2}$ & -0.04 & 0.74 & -0.03 & -0.13 & -0.06 & -0.02 & -0.04 & -0.04 \\
\hline $\mathrm{T}_{3}$ & -0.03 & 0.47 & -0.02 & -0.05 & -0.04 & -0.01 & -0.03 & -0.02 \\
\hline $\mathrm{T}_{4}$ & -0.01 & 0.21 & -0.01 & 0.02 & -0.02 & 0.00 & -0.01 & -0.01 \\
\hline $\mathrm{T}_{5}$ & 0.01 & -0.21 & 0.01 & 0.09 & 0.01 & 0.01 & 0.01 & 0.01 \\
\hline \multicolumn{9}{|l|}{ Rural skilled } \\
\hline $\mathrm{T}_{4}$ & & & & & & & -0.01 & \\
\hline \multicolumn{9}{|c|}{ Urban unskilled } \\
\hline $\mathrm{T}_{1}$ & & 1.07 & 0.01 & -0.22 & -0.03 & 0.06 & -0.01 & -0.01 \\
\hline $\mathrm{T}_{2}$ & -0.01 & 0.77 & & -0.10 & -0.03 & 0.04 & -0.01 & \\
\hline $\mathrm{T}_{3}$ & -0.01 & 0.49 & & -0.03 & -0.02 & 0.03 & -0.01 & \\
\hline $\mathrm{T}_{4}$ & -0.01 & 0.21 & & 0.02 & -0.01 & 0.01 & -0.01 & \\
\hline $\mathrm{T}_{5}$ & & -0.22 & & 0.08 & & -0.01 & & \\
\hline \multicolumn{9}{|l|}{ Urban skilled } \\
\hline $\mathrm{T}_{1}$ & & & 0.01 & -0.21 & -0.02 & 0.06 & & \\
\hline $\mathrm{T}_{2}$ & & & 0.01 & -0.10 & -0.02 & 0.05 & & \\
\hline $\mathrm{T}_{3}$ & & & & -0.02 & -0.02 & 0.04 & & \\
\hline $\mathrm{T}_{4}$ & & & & 0.03 & -0.01 & 0.02 & & \\
\hline $\mathrm{T}_{5}$ & & & & 0.08 & & -0.01 & & \\
\hline
\end{tabular}

\subsubsection{The effect of the tariff increase on GFCF and GDP}

Results from the model predict an increase in both total gross fixed capital formation (GFCF) and gross domestic product (GDP) as the tariff rates increases. This implies that an increase in gross fixed capital formation is essential 
for economic growth, as it is used for enhancing the level of production. This is even important, especially when there is an increase in real private GFCF, as the model predicts the rise of real private GFCF at higher interest rates. This highlights the increase in long-term productive capacity investment in the intended sectors. According to Nunn and Trefler (2010), tariffs can be used to raise government income, if there are increases in importation for the intended sectors. Ongo and Vukenkeng (2014), also argue that increasing private firms' investments enhances technology inflow, which may lead to growth in the scale of production. Further, an increase in GDP is predicted at higher tariff rates, contributed by the fact that higher tariff rates stimulate domestic production, a consequence of the higher price and demand offered for domestically produced commodities, as shown in Table 10.

Table 10. The effects of tariffs increase on GFCF and GDP (\% Change from BAU)

\begin{tabular}{lcccc}
\hline \multicolumn{1}{c}{ Indicator } & \multicolumn{3}{c}{ Tariff rates } \\
\cline { 2 - 5 } & $\mathrm{T}_{1}$ & $\mathrm{~T}_{2}$ & $\mathrm{~T}_{3}$ & $\mathrm{~T}_{4}$ \\
\hline Gross Fixed Capital Formation-GFCF & & & & $\mathrm{T}_{5}$ \\
\hline$\quad$ Real Private GFCF & 0.01 & 0.01 & 0.01 & 0.01 \\
$\quad$ Real Public GFCF & & & & 0.02 \\
$\quad$ Total GFCF & 0.03 & 0.02 & 0.02 & 0.02 \\
Gross domestic products-GDP & & & & 0.01 \\
$\quad$ GDP at basic Price & 0.02 & 0.02 & 0.01 & 0.01 \\
$\quad$ GDP at Market Price & 0.03 & 0.02 & 0.02 & \\
\hline
\end{tabular}

\subsubsection{The effect of the tariff increase on import prices}

Figure 1 shows the impact of tariffs on the prices of different imported commodities. Since taxes are imposed on the edible oils sectors, the model predicts an increase in prices for edible oils while small prices changes are observed in the other sectors. A possible explanation for this trend is that the imposition of tariffs increases costs to importers of edible oils, consequently increasing prices both for imported and domestically produced substitute commodities. While, on the one hand, this situation may look beneficial to local producers, on the other hand, it could negatively impact consumers, as it reduces the surplus that they would have gained from buying imported commodities at lower prices.

\section{Impact of tariff on prices of imported commodities}

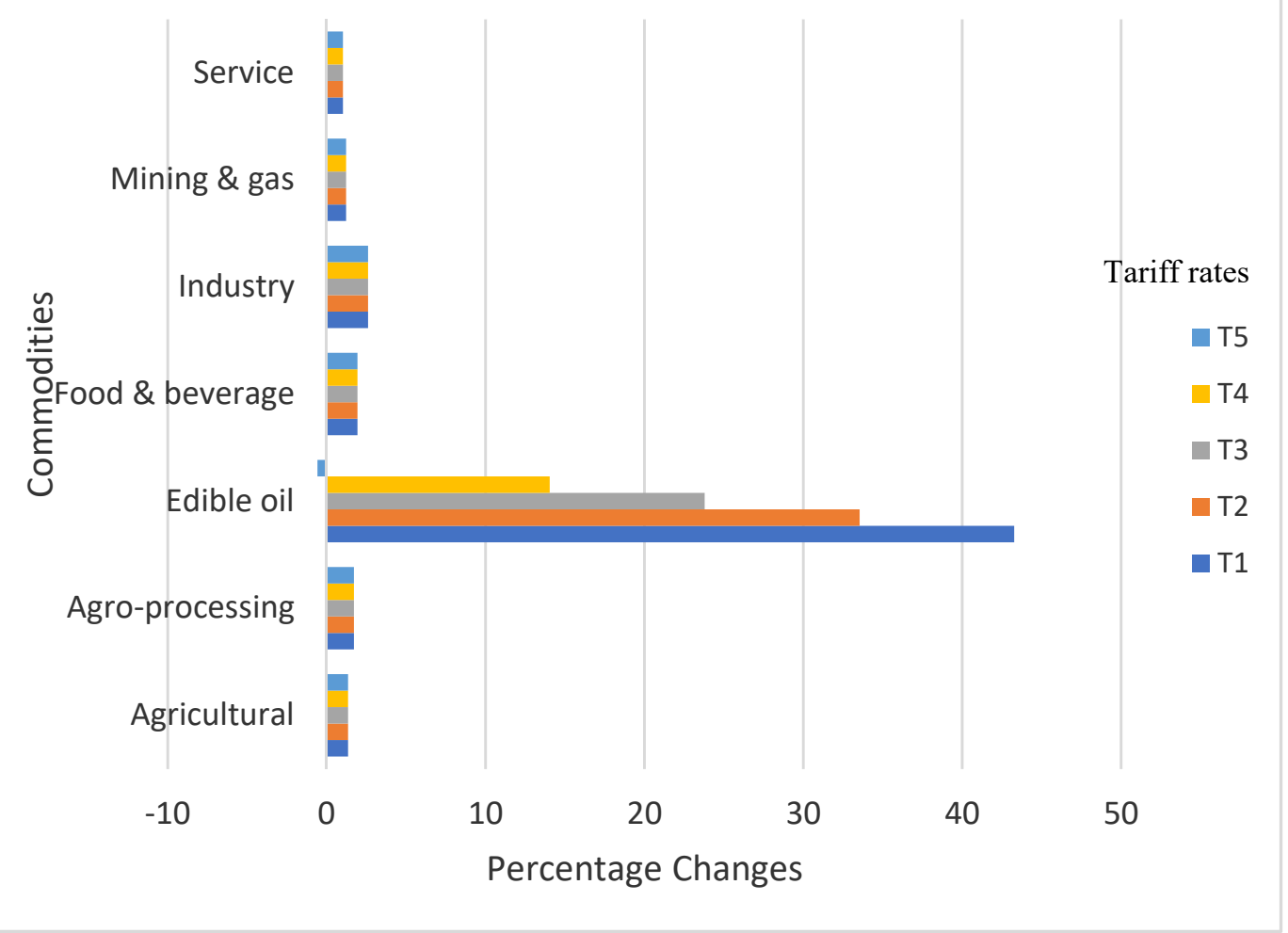

Figure 1. The impact of the tariff increase on prices of imported commodities

4.2.11 The effect of the tariff increase on household commodities' consumption

Results from the model in Table 11 predict a decrease in edible oil consumption at higher tariff rates for all household categories. However, edible oil consumption increases when the tariff is completely removed, thus 
implying that higher tariff rates increase the prices of the produced edible oils, making them unaffordable for consumers. A similar trend in decrease consumption for agro-processed commodities is predicted for rural farming and urban households. Moreover, higher tariff rates negatively affect urban households' consumption for almost all commodities. Similar findings are provided by Boulanger et al. (2016), who evaluate the effect of an agri-food import ban in Russia that resulted in the rise of commodity market prices, consequently reducing consumer utilities in both quantities and varieties. Similarly, Karimi et al. (2016), when investigating the effects of trade liberalization in developing countries, argue that reducing tariffs results in an increase in the consumption of commodities as more product varieties are available in the market at relatively lower prices than when there are trade restrictions. Apart from reducing the edible consumption of rural farming households, the model predicts an increase in expenditures for all other products. This implies that rural farming households adjust their consumption: first, their production is used for home consumption and, second, expanding the production of agricultural commodities increases their income and consumption of non-agricultural products. These model predictions are consistent with those predicted by von Arnim et al. (2018) in their study on the effects of price shocks on commodities in developing countries; they predict that, although rural farming generates income from the agricultural sector as it expands, nevertheless, price shocks caused by government interventions, like import tariffs, increase the prices of agricultural goods, therefore negatively affecting their consumption.

Table 11. The effects of the tariff increase on households' commodity consumption (\% change from BAU)

\begin{tabular}{|c|c|c|c|c|c|c|c|c|}
\hline \multirow{2}{*}{$\begin{array}{l}\text { Household } \\
\text { Category }\end{array}$} & \multicolumn{7}{|c|}{ Commodity } & \multirow[b]{2}{*}{ Service } \\
\hline & $\begin{array}{c}\text { Agricult } \\
\text { ural }\end{array}$ & $\begin{array}{c}\text { Edible } \\
\text { Oils }\end{array}$ & $\begin{array}{c}\text { Food \& } \\
\text { Beverage }\end{array}$ & $\begin{array}{l}\text { Agro- } \\
\text { processin } \\
\mathrm{g}\end{array}$ & $\begin{array}{c}\text { Mining \& } \\
\text { Gas }\end{array}$ & $\begin{array}{c}\text { Indust } \\
\text { rial }\end{array}$ & $\begin{array}{c}\text { Administr } \\
\text { ation }\end{array}$ & \\
\hline \multicolumn{9}{|c|}{ Rural farming } \\
\hline $\mathrm{T} 1$ & 0.02 & -0.49 & 0.04 & 0.02 & 0.05 & 0.09 & 0.04 & 0.04 \\
\hline $\mathrm{T} 2$ & 0.02 & -0.36 & 0.02 & 0.01 & 0.03 & 0.06 & 0.03 & 0.03 \\
\hline $\mathrm{T} 3$ & 0.01 & -0.23 & 0.01 & & 0.02 & 0.04 & 0.02 & 0.02 \\
\hline $\mathrm{T} 4$ & 0.01 & -0.10 & 0.01 & & 0.01 & 0.02 & 0.01 & 0.01 \\
\hline $\mathrm{T} 5$ & & 0.10 & -0.01 & -0.01 & -0.01 & -0.01 & -0.01 & -0.01 \\
\hline \multicolumn{9}{|c|}{ Rural non-farming } \\
\hline $\mathrm{T} 1$ & & -0.33 & 0.01 & -0.01 & 0.01 & 0.02 & 0.01 & 0.01 \\
\hline $\mathrm{T} 2$ & & -0.24 & & -0.01 & 0.01 & 0.02 & 0.01 & 0.01 \\
\hline $\mathrm{T} 3$ & & -0.15 & & -0.01 & & 0.01 & & \\
\hline $\mathrm{T} 4$ & & -0.07 & & -0.01 & & 0.01 & & \\
\hline T5 & & 0.07 & & & & & & \\
\hline \multicolumn{9}{|l|}{ Urban } \\
\hline $\mathrm{T} 1$ & -0.01 & -0.37 & -0.02 & -0.03 & -0.01 & -0.03 & -0.01 & -0.01 \\
\hline $\mathrm{T} 2$ & -0.01 & -0.27 & -0.01 & -0.03 & -0.01 & -0.01 & -0.01 & -0.01 \\
\hline $\mathrm{T} 3$ & & -0.17 & -0.01 & -0.02 & & -0.01 & & -0.01 \\
\hline $\mathrm{T} 4$ & & -0.07 & & -0.01 & & & & \\
\hline T5 & & 0.07 & & 0.01 & & 0.01 & & \\
\hline
\end{tabular}

\subsection{Conclusion and Policy Recommendation}

Tanzania is implementing a policy designed to protect the agriculture sector, intended to promote and stimulate the domestic production of various commodities that subsequently will accelerate industrialization. This paper evaluates the effects of Tanzania imposing an ad valorem tax on imported edible oils, ascertaining the multiplier effects of the intervention in terms of accelerating industrialization, economic growth, and peoples' welfare. A recursive computable general equilibrium model is applied to analyze the economy-wide effects of the imposed tariff on economic growth and industrialization.

Findings from this study show that increasing the tariff on edible oils indeed stimulates the demand and supply of domestically produced edible oils. However, in the short run, the model predicts that the intervention triggers a shortage of edible oils in the domestic market, thus increasing prices, harming consumers by notably decreasing its consumption. Therefore, tariff imposition has two outcomes: first, it incentivizes domestic producers to supply more due to the rise in demand and prices for the commodities, subsequently increasing domestic production in order to meet demand from the economy. The second consequence, from the international trade viewpoint, is that such intervention erodes citizen welfare by limiting the availability and access options to varieties of commodities that could make them better off in terms of prices, qualities, and quantities. This indicates that tariff interventions should be accompanied by efforts geared toward improving domestic productivity like knowledge transfer through extension services. Productivity improvements increase domestic outputs and enable the processing industries of the commodities in question to achieve economies of scale and accelerate industrialization. In addition, consumers can fill the welfare losses caused by the importation barrier strategy, as varieties of products with lower prices and 
better qualities become available in the markets. This also assumes a situation that the markets transform towards very quick competitiveness with international world market systems.

Moreover, the model predicts an increase in income for all domestic agents: rural farming, non-farming, and urban households, as well as the government and firms. This indicates that tariff interventions motivate farmers to expand and employ more factors of production, such as labor and capital, to produce more in order to meet the demand for domestically produced commodities, which then increases household income. Here alternative higher factor-use in other dynamic market developments is neglected and cannot be predicted (ceteris paribus analysis). For the government, high tariff rates, coupled with increased production, expand the tax revenue base. In contrast, a decrease in the quantity of imported edible oils decreases income inflow from the rest of the world. Therefore, the welfare gains resulting from the increase in incomes for the domestic economic agents and institutions signal achievement of the Tanzanian government's prime objective, which is to create inclusive income growth for the citizens.

In line with the agents increasing production and their incomes, the model results also indicate an increase in saving for all households' categories and for firms. In addition, the model predicts an increase in sectoral investment demand for capital and land. This is a positive indicator: as most production processes are carried out by the private sector, an increase in savings will facilitate the capital accumulation and investment at various nodes throughout the intended commodities' value chains that can accelerate industrialization in the long run.

There is one important conclusion: the rise in tariffs for imported edible oils will cause an increase in demand for domestically produced edible oils, which subsequently simulates domestic production. Indeed, such an intervention can be used as a strategy to protect and nurture domestic industries as they benefit both from the economy of scales and from less competition with imported substitute products. However, protectionist policies create a commodities supply deficit in the market that reduces consumers' welfare, when these are solely used as a solution to increase domestic production in a sector that is inefficient in terms of productivity.

Therefore, for sustainability, the government of Tanzania must promote policies and interventions that target the increasing productivity of small, medium, and large industries. The tariff should be used only for a time to access markets and to install competitiveness among domestic edible oil producers. Interventions that increase smallholder farmer's productivity, like the use of improved seed and other modern technologies that reduce costs of production, are critical as commodities will be sold at slightly competitive premiums or the same prices as imported commodities. However, research on the impact of increasing productivity of a sector should be done to highlight the multiplier effects in the economy. In addition, although the government has reduced or removed import duties on imported agricultural-related inputs and machinery, more supports are needed to grow the industry in terms of capital and creation of a conducive business environment. This will entice both foreign and domestic investors to invest in the intended sectors, accelerating the Tanzanian vision of becoming a semi-industrialized and middle-income country by 2025 .

\section{Acknowledgments:}

The authors acknowledge a grant from the Germany Federal Ministry of Food and Agriculture under the auspices of the Federal Office for Agriculture and Food. We also appreciate the support from the Leibniz Centre for Agricultural Landscape Research (ZALF. e.V). Additional gratitude is due to the Partnership for Economic Policy (PEP) Network and the IFPRI-Nexus project for making the model code and Tanzania's 2015 SAM available, respectively. Finally, we thank the anonymous reviewers and editors for their constructive comments, which substantially improved this study.

\section{References}

Adewale, A. R. (2017). Import substitution industrialization and economic growth - Evidence from the group of BRICS countries. Future Business Journal, 3(2), 138-158. doi:10.1016/j.fbj.2017.06.001

Aragie, E., Pauw, K., and Pernechele. V. (2018). Achieving food security and industrial development in Malawi: Are export restrictions the solution? World Development, 108: 1-15.

Balchin, N., J. Kweka, and Mendez-Parra, M. (2018). Tariff setting for Development of Edible Oil Sector in Tanzania. Agricultural State Actors Forum(ANSAF). Final Report. Pp. 79. Available online: http://dev.ansaf.or.tz/wp-content/uploads/2018/04/I4ID-Tariff-setting-in-Tanzanias-edible-oilsector FINAL-Report 26-Feb-2018.pdf. (accessed in September 2018).

Boulanger, P., H. Dudu, E. Ferrari, and G. Philippidis. (2016). Russian Roulette at the Trade Table: A Specific Factors CGE Analysis of an Agri-food Import Ban. Journal of Agricultural Economics 67(2), 272-291. doi: $10.1111 / 1477-9552.12156$

Bouet, A., L. Cosnard, and D. Laborde. 2017. Measuring Trade Integration in Africa. IFPRI Discussion Paper 1667. Available at SSRN: https://ssrn.com/abstract=3029635

Bezemer, D., and D. Headey. (2008). Agriculture, Development, and Urban Bias World Development 36(8): 13421364. 
BoT, (2018). Bank of Tanzania Annual Report 2016/17. 254. Available online: https://www.bot.og.tz (accessed on 10 August 2018).

Bresnahan, L., I. Coxhead, J. Foltz, and T. Mongues. (2016). Does Freer Trade Really Lead to Productivity Growth? Evidence from Africa. World Development 86, 18-29. http://dx.doi.org/10.1016/j.worlddev.2016.05.007

Clapp, J. (2017). Food self-sufficiency: Making sense of it, and when it makes sense. Food Policy 66: 88-96.

Chang, H. J. (2012). Kicking away the ladder: Neoliberalism and the 'Real' History of capitalism. In: K.-S. Chang, L. Weiss, \& B. Fine (Eds.), Developmental politics in transition - The Neoliberal era and beyond (pp. 4350). Hampshire, United Kingdom: Palgrave Macmillan

Chisoro-Dude, S., T. Paremoer, C. Jahari, and B. Kilama. (2018). Growth and development of oilseeds-edible-oils value chain in Tanzania and South Africa. Working paper, Centre for competition, regulation and economic development-CCRED, University of Johannesburg, Johannesburg, South Africa.

Chongela, J. (2015). The contribution of the Agriculture Sector to the Tanzanian Economy. American Journal of Research and Communication 3(7),57-70.

Chen, S., and M. Ravallian. (2013). More Relatively-Poor People in a Less Absolutely-Poor World. Review of Income and Wealth 59 (1), 1-28.

Cicowiez, M., J. Alejo, L. Di Grecia, S. Olivieri, and A. Pacheco. (2016). Export taxes, World prices, and poverty in Argentina: A Dynamic CGE-Microsimulation Analysis, International Journal of Microsimulation 9(1), 24-54.

Cramer, C. (1999). Can Africa Industrialize-by Processing Primary Commodities. World Development, 27(7), 1247-1266.

CTI, (2000). The Manufacturing Sector in Tanzania, the study be a confederation of Tanzania Industries (CTI) and the Confederation of Danish Industries (DI), Final report, 83.

De Ferranti, D., G. E. Perry, D. Lederman, and W. E. Maloney, (2002). From natural resources to the knowledge economy: trade and job quality. World Bank Latin American and Caribbean Studies 23440. World Bank, Washington, DC.

Decaluwé, B., A. Lemelin, V. Robichaud, and H. Maisonnave. (2013). The PEP 1-t Standard Computable General Equilibrium Model: single-country, Recursive Dynamic Version (Version 2.1), Politique économique et Pauvreté/Poverty and Economic Policy Network, Université Laval, Québec

Diao, X., J. Thurlow, S.Benin, and, S. Fan (2012). Strategies for African Agriculture: Economic Perspective from Countries studies, International Food Policy Research Institute, Washington D.C. Doi: http://dx.doi.org/10.2499/9780896291959

Fosu, A. K. (2011). Growth, Inequality, and poverty reduction in developing countries: recent global evidence. Working paper 2010/01. United Nations University World Institute of Development Economics Research, Helsinki.

Féménia, F., and A. Gohin. (2011). Dynamic modeling of agricultural policies: The role of expectation schemes. Economic Modelling 28(4): 1950-1958.

Flentø, D., and S. Ponte. (2017). Least-Developed Countries in a World of Global Value Chains: Are WTO Trade Negotiations Helping? World Development 94: 366-374.

Hübler, M., and F. Pothen, (2017). Trade-induced productivity gains reduce incentives to impose strategic tariffs. Economic Modelling 61, 420-431.

International Food Policy Research Institute (IFPRI), (2017). 2015 Social Accounting Matrix for Tanzania, https://doi.org/10.7910/DVN/PPXXD9, Dataverse, V1. (accessed on January 5, 2018).

Jerven, M., and M. E Duncan. (2012). Revising GDP estimates in Sub-Saharan Africa: Lessons from Ghana. The African Statistical Journal 15.

Jerven, M. (2010). Accounting for the African Growth Miracle: The Official Evidence - Botswana 1965-1995. Journal of Southern African Studies 36(1), 73-94. doi:10.1080/03057071003607337

Karimi, M., S. R. Kaliappan, N. W. Ismail, and H. Z. Hamzah. (2016). The Impact of Trade Liberalization on Tax Structure in Developing Countries. Procedia Economics and Finance, 36, 274-282. doi:10.1016/s22125671(16)30038-7

Kombe, C., Z. Mpemba, N. Yabu, M. Kazi, J. Machemba, B. Kibesse, D. Mwita, E. Mgangaluma, S. Mashine, A. Chaula, E. Nduguru, M. Lugobi, and M. Mziya. (2017). Potentiality of Sunflower Sub-sector in Tanzania. Bank of Tanzania Working paper, 10.

Kosack, S., and J. L. Tobin. (2015). Which Countries' Citizens Are Better Off With Trade? World Development 76, 95-113. doi:10.1016/j.worlddev.2015.05.021

Koopman, R., W. Zhi, and W. Shang-Jin, (2014). Tracing Value-added and Double Counting in Gross Exports. American Economic Review 104(2):459-494.

Laborde, D., C. Estrades, and A. Bouet. (2013). A global assessment of the economic effects of export taxes. The World Economics 94 (2) 435-441.

Laborde, D., and F. Traore, (2017). The sensitivity of Computable General Equilibrium Models to 
Macroeconomics Closure Rules: evidence from IFPRI Standard Model, AGRODEP Technical Notes. IFPRI, Washington, DC, USA.

Le Goff, M., and R. J. Singh. (2014). Does trade reduce poverty? A view from Africa. Journal of African Trade 1(1), 5-14. Doi:10.1016/j.joat.2014.06.001.

Lectard, P. and E. Rougier (2018). Can Developing Countries Gain from Defying Comparative Advantage? Distance to Comparative Advantage, Export Diversification and Sophistication, and the Dynamics of Specialization. World Development 102: 90-110.

Laborde, D. and F. Traore. (2017). The sensitivity of Computable General Equilibrium Models to Macroeconomic Closure Rules: Evidence from the IFPRI Standard Model. AGRODEP Technical Note 0015. pp. 95

Mbayi, L. (2013). Turning Rough Dreams into a Polished Reality? Investigating the formation of Human Capital in Botswana's Diamond Cutting and Polishing Industry, (Ph.D. Thesis) Open University.

Mbayi, L. (2011). Linkages in Botswana's Diamond Cutting and Polishing Industry. MMCP Discussion Paper 6. University of Cape Town and Open University.

Mgeni, C. P. S., Sieber, T. S. Amjath-Babu., and K. D. Mutabazi. (2018). Can protectionism improve food security? Evidence from an imposed tariff on imported edible oil in Tanzania. Food Security 1-8. doi:10.1007/s12571017-0746-3

Mitra, D., and J. Shin. (2012). Import protection, exports, and labor-demand elasticities: Evidence from Korea. International Review of Economics \& Finance 23, 91-109. doi:10.1016/j.iref.2011.10.008

Msami, J. and S. Wangwe. (2016). Industrial development in Tanzania. In Manufacturing Transformation: Comparative Studies of Industrial Development in Africa and Emerging Asia. 6(38), Newman, C. Page, J. Rand, J. Shimeles, A. Söderbom, M. and Tarp, F. Eds. 2016, 45-66. doi:10.1093/acrof:oso/9780198776987.003.0008.

Mkubwa, H. M., B. A. Mtengwa, and S. A. Babiker. (2014). The Impact of Trade Liberalization on Economic Growth in Tanzania. International Journal of Academic Research in Business and Social Sciences 4(5). doi:10.6007/IJARBSS/v4-i5/879.

Mufuruki, A. A., R.Mawji, G. Kasiga, and M. Marwa (2017). Tanzania's Industrialisation Journey, 2016-2056, From an Agrarian to a Modern Industrialised State in Forty Years. Moran (E.A.), Nairobi, Kenya, 190.

Mwang'onda, E. S., S. L. Mwasebaand M. S. Juma. (2018). Industrialization in Tanzania: The Fate of the Manufacturing sector Lies upon Policies Implementations. International Journal of Business and Economics Research 7(3), 71-78. doi:10.11648/j.ijber.20180703.14.

Makwiramiti, M. A. (2011). BRICS: A Friendship of Convenience? Consultancy Africa Intelligence. Available online: http://www.consultancyafrica.com/index.php? Option $1 / 4$ com content\&view $1 / 4$ article\&id $1 / 4789$ :bricsa-friendship-of-convenience-\&catid 1/487: African-finance-a-economy\&Itemid $1 / 4294$. Accessed on January 15 , 2019

Morris, M., and J. Fessehaie. (2012). Making the most of Africa's commodities: linkage development, value addition, and industrialization. Report for the Economic Commission on Africa.

Morris, M., and J. Fessehaie, (2014). The industrialization challenge for Africa: Towards a commodities-based industrialization path. Journal of African Trade 1(1), 25-36. Doi:10.1016/j.joat.2014.10.001.

Minor, P., et al. (2017). State-owned enterprise reform in Vietnam: A dynamic CGE analysis. Journal of Asian Economics.

Naranpanawa, A., and R. Arora, (2014). Does Trade Liberalization Promote Regional Disparities? Evidence from a Multiregional CGE Model of India. World Development, 64, 339-349. doi:https://doi.org/10.1016/j.worlddev.2014.06.001

Nunn, N., and D. Trefler, (2010). The Structure of Tariffs and Long-Term Growth, American Economic Journal: Macroeconomics, 158-194.

Ongo, E. N., and A. W. Vukenkeng. (2014). Does gross capital formation matter for economic growth in the CEMAC sub-region? EuroEconomica, 33 (2)

Pratt, S., A. Blake, and P. Swann. (2013). Dynamic general equilibrium model with uncertainty: Uncertainty regarding the future path of the economy. Economic Modelling 32: 429-439. DOI: 10.1016/j.econmod.2013.02.034

Page, J. (2012). Can Africa Industrialize? Journal of African Economy 21, 2, 86-124.

Porteous, O. 2017. Empirical effects of short-term export bans: The case of African maize. Food Policy, 71, $17-$ 26. doi:https://doi.org/10.1016/j.foodpol.2017.07.003

Pothen, F., and H. Welsch. (2019). Economic development and material use. Evidence from international panel data. World Development, 115, 107-119. doi:10.1016/j.worlddev.2018.06.008

Raihan, S., S. Osmani, and B. Khalily. (2017). The macro impact of microfinance in Bangladesh: A CGE analysis. Economic Modelling 62: 1-15. DOI: 10.1016/j.econmod.2017.01.002

Samouel, B., and B. Aram. (2016). The Determinants of Industrialization: Empirical Evidence for Africa, European Scientific Journal 1857-7431. 
Szirmai, A., and P. Lapperre. (2001). The Industrial Experience In Tanzania. New York: Palgrave

Taylor, L. (2016). CGE applications in development economics. Journal of Policy Modeling 38(3): $495-514$.

TEOSA (2012). Assessment of the Potential of Edible Oilseeds Produced in Tanzania: The Case of Sunflower and Sesame: 48.

Thomas, L., G. K. Jha, and S. Pal. (2013). External Market Linkages and Instability in Indian Edible Oil Economy: Implications for Self-sufficiency Policy in Edible Oils. Agricultural Economics Research Review, 26(2) 185198.

Tvaronavičius, V., and M. Tvaronavičiene. (2008). Role of fixed investments in economic growth of country: Lithuania in a European context. Journal of Business Economics and Management, 9(1), 57-64. doi:10.3846/1611-1699.2008.9.57-64

The United Republic of Tanzania, (2018). Nations population projections, National Bureau of Statistics, Ministry of Finance and Planning, Dar es Salaam, Tanzania. Available online: https://www.nbs.go.tz/nbs/takwimu/cnsus2012/Projection-Report-20132035.pdf (accessed on January 9, 2019)

Ugulumu, E. S., and E. L. Inanga (2013). Tanzania's Small-Scale Sunflower Farmers: Upgrading the Value Chain. International Journal of Sciences: Basic and Applied Research (IJSBAR) 10(1): pp 126-145.

URT, (2015). United Republic of Tanzania Sunflower Sector Development Strategy 2016-2020. Available online: http://unossc1.undp.org/sscexpo/content/ssc/library/solutions/partners/expo/2016/GSSD\%20Expo\%20Duba i\%202016\%20PPT/Day\%202_November\%201/SF\%204_Room\%20D_ITC/Value\%20chain\%20roadmaps/ Tanzania/Tanzania\%20Sunflower\%20Sector\%20Development\%20Strategy.pdf (accessed on 10 July 2018).

URT, (2016). Agricultural Sector Development Programme Phase Two (ASPD II), Government Programme Document. Available online: http://www.tzdpg.or.tz/fileadmin/documents/external/national_development_frameworks/ASDP2_Final_Do cument_20_May._2016_after_edit_1_.pdf. (accessed on 5 August 2018).

UNIDO, (2012). Tanzania Industrial Competitiveness Report 2012. Dar es Salaam, Tanzania

Van Ha, P. and T. Kompas. (2016). Solving intertemporal CGE models in parallel using a singly bordered block diagonal ordering technique. Economic Modelling 52: 3-12.

von Arnim, R., B. Tröster, C. Staritz, and W. Raza. (2018). Commodity price shocks and the distribution of income in commodity-dependent least-developed countries. Journal of Policy Modeling 40(2), 434-451. doi:10.1016/j.jpolmod.2018.02.008

Wangwe, S., D. Mmari, J. Alkaeli, N. Rutatina, T.Mboghoina, and Kinyondo, (2014). The performance of the manufacturing sector in Tanzania: Challenges and way forward. Working paper.

Yu, E.T.-H., S. Tokgoz, E. Wailes, and E. Chavez. (2011). A quantitative analysis of trade policy responses to higher world agricultural commodity prices. Food Policy 36(5), 545-561. doi:https://doi.org/10.1016/j.foodpol.2011.07.001 